\title{
Construction of Teaching Quality Assurance and Monitoring System for Applied Talent Cultivation
}

\author{
Xiaoji GUAN* \\ Shandong Technology and Business University \\ Yantai China \\ e-mail:1lj2002-1@163.com
}

\begin{abstract}
This paper focuses on improving the quality of applied talents. We study objects with constructing the teaching quality assurance and monitoring system, mainly including the connotation, composition and relationship among the system. Our results show that the control factor system is the core factor of the system, which determines the quality of applicationoriented talent cultivation. The organization management system is its key factor; it controls the whole system operation process and the operation quality. These results demonstrate that monitoring and feedback control are necessary to realize system optimization.
\end{abstract}

Keywords - teaching quality assurance and monitoring system; applied talents; closed-loop system; reform and innovation

\section{INTRODUCTION}

High-quality higher education is an important engine for cultivating applied and innovative talents to realize the national modernization and the great rejuvenation of China. The social and economic development of our country needs different types of applied talents. There is a phenomenon of assimilation in the professional setting of colleges and universities in China, talent cultivation lacks personalization, and the school positioning feature is not outstanding. The state council on accelerating the development of modern vocational education decision "(2015), countries should guide the transformation development of ordinary undergraduate course colleges and universities, encouraging its location for application technology types of institutions of higher learning. Especially provincial undergraduate course colleges and universities combined with the regional economic development, encourage the professional setting characteristics, to cultivate applied talents. In particular, to encourage provincial universities to integrate regional economic development, set up characteristic specialty, cultivate applied talents. The Ministry of Education promulgated the National Standard for the Teaching Quality of Undergraduate Majors in Ordinary Institutions of Higher Learning, which also emphasizes that teaching affairs should establish a teaching quality assurance system.

With this opportunity, how to combine the country's professional standards, build a quality monitoring system in line with the application of personnel training has become an urgent need. The system aims at improving the quality of applied personnel training, adhere to educating people primarily, deepen teaching reform, improve the quality of

Shandong province high level applied industrial engineering group construction project in 2016. education and form a distinctive application-type talent training system to cultivate a large number of high-quality applied talents with features like solid foundation, simple style, strong adaptability, strong practical abilities, social responsibility, innovative spirit and employment competitiveness. Meet the needs of talent in the new situation and new development environment is urgent demand for local universities.

\section{Construction of Teaching Quality Guarantee AND MONITORING SYSTEM FOR APPLIED TALENTS}

\section{A. The Connotation of the Guarantee Quality and Supervision System of Applied Talents}

The teaching quality guarantee and monitoring system of applied talents cultivation aims at the training of applied talents, follows the rules of applied talent cultivation, adopts certain methods, methods and means, and establishes applied quality standards and information collection, monitoring and feedback systems. Forming a closed-loop system to monitor and control all key links and elements that affect teaching quality, so as to ensure that the teaching quality reaches the expected goal of the training of application-oriented professionals[1].

The real-time control in the teaching quality assurance and monitoring system for the training of applied talents involves human intervention in the system according to the requirements of the objectives (quality of personnel training or teaching effectiveness) and possible deviations in the system before and during the operation of the teaching system. Influenced by the achieved control.

The teaching quality guarantee of applied talent cultivation and real-time control in the monitoring system is the control form with human intervention and influence focus on the possible deviations from the objectives and requirements of the system before and during the operation of the teaching system. The feedback control is to adjust and control the teaching system according to the deviation between the output of the system and the predetermined target of the system to minimize the deviation[2].

\section{B. Composition of teaching quality assurance and monitoring system for applied talents}

The teaching quality assurance and monitoring system generally includes the sum of the teaching system associated with the daily teaching activities and other relevant systems 
that ensure the smooth implementation of the teaching objectives. It can also call a control factor system, which is a factor that has an important influence on the teaching quality.

The quality standard system refers to the quality standard of teaching activities and auxiliary links related to teaching activities. In order to adapt to the needs of talents at different levels, in different industries and in different regions, the objectives of the cultivation of applied talents should reflect the characteristics of diversified development, which will inevitably lead to the diversification of quality standards.

The monitoring and evaluation system is a system that collects various information, data, and data on the quality of teaching (including all aspects of theoretical teaching and practical teaching) and analyzes and evaluates them. This part should increase the proportion of various factors in the application of personnel training, try to adopt quantitative assessment criteria or weighting the main factors, highlight the importance of practice.

The organization management system is the collection of organizations directly related to teaching work in the teaching quality assurance and monitoring system and directly related to the teaching quality and teaching effectiveness. Institutions incorporated into the organizational system need to be determined according to the actual situation of the operation of education and teaching in different institutions of higher learning. There are basically three parts: First, institutions that represent schools in teaching quality assurance and monitoring; Second, grass-roots units directly engaged in education and teaching (College or department); Third is a functional department that has a direct relationship with teaching work and has a direct impact on teaching quality[2].

To ensure the smooth implementation of the applicationoriented talent training objectives, the organization system is mainly responsible for formulating systems and policies that are conducive to the training of applied talents, and promoting new policies and measures in teaching activities to formulate quality standards that reflect the characteristics of the training of applied talents. The evaluation system changes to a single evaluation of multiple evaluations, and the relevant departments raise awareness and cooperate closely.

The teaching security system is the collection of organizations that provide conditional guarantees for teaching work (including improving teaching quality) in teaching quality assurance and monitoring systems. This system provides the necessary basic conditions for people, finances, and materials for the normal operation of teaching and the continuous and stable improvement of teaching quality.

\section{The Characteristics of the Teaching Quality Assurance and Monitoring System for Applied Talent Cultivation}

The so-called applied talents are relative to academic research talents. They refer to skilled talents who can apply mature technologies and theories to production and life practices and have strong professional conversion and migration skills[3].

In general, applied talents are highly-coordinated and innovative talents with "knowledge, ability, and quality". The training goal is to emphasize the ability as the main line, persist in full training, highlight practical links, and strengthen comprehensive assessments[4]. Therefore, the teaching quality monitoring system guided by applied talent cultivation has the following three characteristics.

1)Highlight the ability. The training of applied talents highlights students' comprehensive qualities of practical skills, social adaptability, and innovative ability, and highlight that "ability is the core". Therefore, we should design theoretical teaching, practical teaching, examination assessment, evaluation feedback and guarantee system that are conducive to cultivating applied talents based on the three dimensions of "knowledge, ability, and quality". We should focus on stimulating students' interest and potential in learning, innovation, and reforms. Teaching methods, strengthening practice, and promoting the transformation of undergraduate teaching from "teaching well" to "learning well". Form a management monitoring system that comprehensively cultivates students' practical ability and overall quality. In particular, strengthen skills training and corporate practice. Meanwhile, examination content and assessment methods should also be reformed and innovated in the examination and assessment process, and the measure scores for highlighting abilities should be increased. The protection and monitoring system should also focus on the cultivation of students' ability to conduct comprehensive and comprehensive protection and services.

2)Strengthen quality first. Firstly, strengthen the quality awareness of teachers and teaching managers, raise awareness of the significance of teaching quality, and fully mobilize their own requirements and internal enthusiasm for improving teaching quality, so that they can consciously and voluntarily deepen teaching reform, vigorously improve teaching work, and strive to improve teaching. Quality, establish a teaching quality operating mechanism with both incentive and constraint functions, and teachers and management personnel reach a consensus of "quality first". Secondly, formulate a system of quality evaluation standards with complete systems and leading indicators, redesign the evaluation criteria of "quality first" from the monitoring of teaching process and monitoring of practice links, and make a scientific evaluation of the entire teaching process. Finally, the collection and evaluation system of information includes real-time monitoring and regular feedback, timely detection of problems, timely correction of content that affects the quality of personnel training, and corrections.

3)Continuous improvement principle. The real-time control and feedback control of the teaching process is the key to guarantee the quality of teaching. The monitoring of teaching quality in colleges and universities is a very complex and diversified space. It involves many common problems of colleges and universities, and it is more and more systematic and dynamic[5]. In the management of education and teaching quality, the teaching quality assurance and monitoring system itself is a dynamic system, and the relationship between its internal elements and elements is continuously changing. In order to ensure the teaching quality and the training goal of high quality application-oriented talents, the university should maintain the normalization of the supervision and management 
of the teaching quality system. Adjustments with the demand of social changes, such as the adjustment of the professional, personnel training target, course setting, teaching content and teaching method improvement, etc., to combine the normal monitoring and regular evaluation. Timely evaluate and feedback and continuously improve the quality of personnel training.

\section{THE OpERATIONAL QUALITY GUARANTEE AND MONITORING SYSTEM OF APPLIED TALENTS}

The object of teaching quality assurance and monitoring is a complete system composed of all links, departments, and personnel involved in the formation of teaching quality. A monitoring system of teaching quality with a reasonable internal structure and strict and unobstructed quality should be a closed-loop system that includes a control element system, a teaching quality monitoring and evaluation system, a quality standard system, an organization management system, and a teaching security system (as shown in Fig. 1).

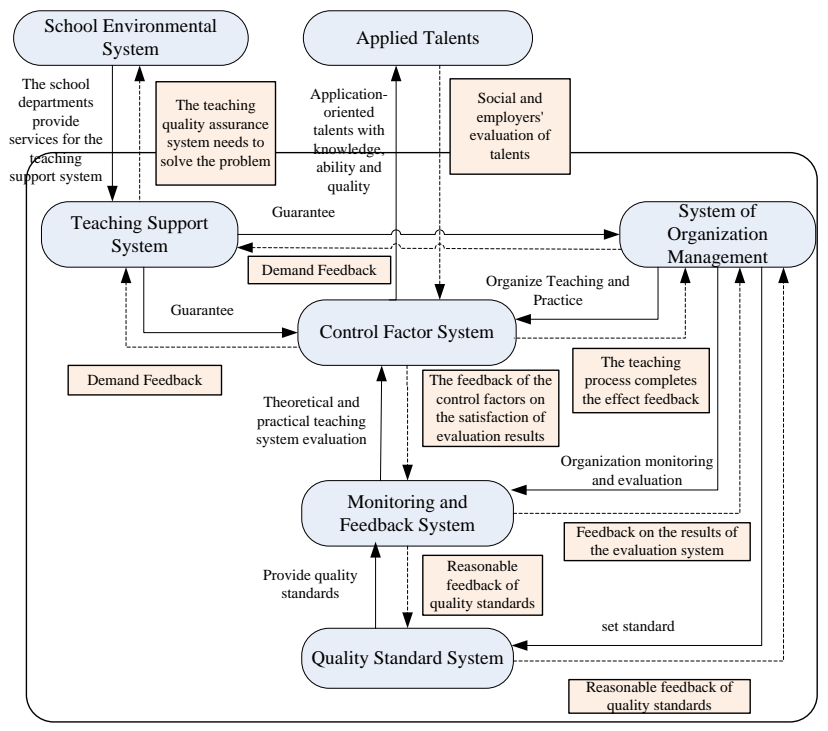

Fig. 1. Applied Talents Teaching Quality Guarantee and Monitoring System

As shown in the figure, as a closed-loop system, internal information flow is a quality assessment standard and evaluation result. Among them, positive information flow is a quality evaluation standard and a series of related factors. Positive flow control loops is: security system (provide security conditions) - organization system (formation of quality standards) - quality standards system (support for monitoring systems) - monitoring and evaluation system (reference quality standards evaluation theory and practice teaching) - control Factor system (teaching effect feedback) - organization system (guaranteed demand feedback), it is a constantly monitoring system. The feedback information flow is a feedback factor related to the evaluation result and the evaluation result. The feedback flow closed-loop system is: control factor system (evaluation result satisfaction feedback)-monitoring and evaluation system (quality standard rationality feedback)quality standard system (quality Standard rationality feedback) - Organizational system (guaranteed demand feedback) support system (provide supporting) - Control factor system, it's a feedback control system. The internal quality standard deviation of the system is fed back to the organizational system, and the internal demand of all kinds of resources (people, wealth and things) is fed back to the system.

The teaching quality assurance and monitoring system is also an open system. It exchanges information and energy with the external environment of the system-the school environment system and the applied talent system. Through the teaching security system, various resources are provided for the teaching quality assurance system. Service; Through the control factor system, train qualified application talents for the society and employers, and feedback social and employers' evaluation of talents to the control factor system, so that it is convenient for the system to achieve the correctness of deviations in personnel training objectives[6].

The control factor system is a system that directly applies applied talents. The main objective of the system is to train high-level applied talents with high quality, strong social competitiveness and innovative ability. The quality of the system directly determines the quality of the training target for applied talents and is a key link in the system. Therefore, the quality of theoretical teaching and practical teaching must be greatly improved. The adjustment and improvement of system elements should focus on the core factors related to training applied talents.

Firstly, optimize talent training programs; increase the proportion of practice and practical training in the total number of hours, practice and practical training curriculum plans and training objectives, practice links, and practical training curriculum design to increase students' ability to train and train students. To part-time or internships, the number of internship bases, and the joint training of schools and enterprises, etc., highlight the students' actual hands-on capabilities, operational capabilities, ability to analyze problem-solving problems, and the cultivation of innovative abilities.

Secondly, reforms and innovations in school teaching methods and teaching methods, such as mobile information technology, online education platform, admiration and mixed teaching, case teaching and other means and methods, stimulate students' interest in learning and enthusiasm.

Thirdly, reforms in the examination and examination method reforms are conducted to evaluate students in diverse ways from learning ability, innovation ability and practical ability. The control factor system optimizes and adjusts the internal system according to the quality standards, and feedbacks the satisfaction degree of the evaluation result to the quality standard system, and feedbacks the organization and implementation of the teaching process to the organization management system, facilitating the organization management system to timely adjust the management strategy.

The organization management system is the core link of the teaching quality assurance and monitoring system. The theory and practice teaching organization of the control factor system, the quality standard system for evaluating the teaching quality, and the process of monitoring and evaluating the teaching quality monitoring, analysis and arrangement are all managed by the organization. The system is completed. The organization 
management system is usually composed of the Academic Affairs Office of the university and the secondary college office. The main measures are to improve the quality awareness of the staff of the teaching organization and management department, improve their overall quality, strengthen the management ability and management level training, and make updates. The management system and quality standards adapted to the training of applied talents are organized to conduct real-time monitoring, including the system of lectures, supervision, student evaluation, and internship training courses, to ensure the realization of personnel training goals. The organization management system receives feedback from the teaching organization of the control factor system and evaluation results fed back by the evaluation system. Re-adjust the relevant countermeasures and systems through the analysis and study of the effectiveness of teaching process monitoring results and evaluation results to achieve optimal application-oriented personnel training programs.

The quality standard system includes the evaluation system of theory course teaching evaluation system and practical training course. The evaluation of theory course should emphasize the weight of teaching reform. For example, teachers who adopt new teaching methods, new teaching methods and information technology should be rewarded by the school. The evaluation of practice teaching should highlight the content of students' ability cultivation, pay attention to process management and stage assessment, and focus on the evaluation of students' learning effect. Students are encouraged to go deeper into the enterprise in production practice and graduation practice, and the performance evaluation is skewed towards this part of students. The quality standard system should be revised and adjusted in time.

The teaching security system is the premise and guarantee of the control factor system and the organization management system. It provides support for the control factor system and the organization management system in terms of people, finances, and materials.

In terms of talent demand, we will actively introduce application-oriented talents to train the much-needed teachers, formulate incentive policies, encourage in-service teachers to participate in various examinations or go to enterprises for training, shift to "double-teacher type", and employ outside experts to ensure protection the needs of personnel training.

In terms of financial resources, in order to complete the transition to applied talent training goals, schools should invest a lot of money to improve the laboratory construction and formulate relevant policies, guide service departments to tilt toward the training of applied talents, and increase laboratory construction. And the improvement of basic teaching conditions to ensure the smooth implementation of applicationoriented personnel training objectives.

\section{CONCLUSION}

The teaching quality assurance and monitoring system is an important guarantee for guaranteeing the quality of applied talents in colleges and universities. This paper analyzes the connotation and composition of the teaching quality assurance system and the characteristics that should be possessed by applied talents. It holds that the teaching quality assurance and monitoring system is a closed-loop system and an open system at the same time, and the details of the structure and relationship of the system are detailed. Through argumentation and analysis, it is concluded that the control factor system is the core factor that determines the quality of application-oriented personnel training; the organization management system is the key factor that controls the operation process and operation quality of the entire system; the quality standard system and the monitoring and evaluation system are auxiliary systems. The management and management systems of the organization and management system are tools and means to manage the system of control factors. The teaching and guarantee system ensures the demand for talent, finance, and materials for the normal operation of the control factor system and the organization system, and timely adjusts the supply security through the received feedback information.

\section{ACKNOWLEDGMENT}

Thanks to the financial support provided by the construction project of high level applied industrial engineering in Shandong province in 2016.

\section{REFERENCES}

[1] Kun Lun WANG, Na WANG and Xian XU, the construction and practice of teaching quality monitoring system in applied undergraduate colleges. Journal of HeFei university (natural science edition), 2014(02): 41-45. (In Chinese)

[2] Hai Sheng GAO et al. Construction and practice of higher education $n$ teaching quality assurance monitoring system. Education research, 2006(10): 89-92. (In Chinese)

[3] Guo Ying QIAN, Gang WANG and Li Qing XU, the characteristics of applied talents and the construction of their training system. Chinese university teaching, 2005(09): 54-56. (In Chinese)

[4] Jian Hui PI, Wei Jin LIU and Dan YANG, The principle and implementation strategy of teaching quality control based on application-oriented personnel training. High education journal, 2017(21): 52-54. (In Chinese)

[5] Ji Feng YU, systematic scientific analysis of teaching quality monitoring in colleges and universities. Journal of National Academy of Education Administration, 2005(01): 68-72. (In Chinese)

[6] Jing Fang GONG, construction and implementation of the teaching quality assurance and monitoring system of application-oriented independent college. Journal of higher education, 2017(11): 32-33. (In Chinese) 